\title{
A Family Plot
}

\section{MARTIN EDMOND}

\begin{abstract}
This essay begins with an account of the circumstances which led to my parents owning a Colin and Anne McCahon children's painting. Then it expands upon certain biographical questions raised (or not raised) in my 2011 book Dark Night: Walking with McCahon. I describe the work I did in 2018 with Finn McCahon-Jones, Colin's grandson, on the Visitor Narrative for the McCahon House Trust; and conclude with some thoughts upon the limitations of biography as a genre. Implicit in the discussion is a comparison, hopefully unforced, between my own family and that of the McCahons.
\end{abstract}

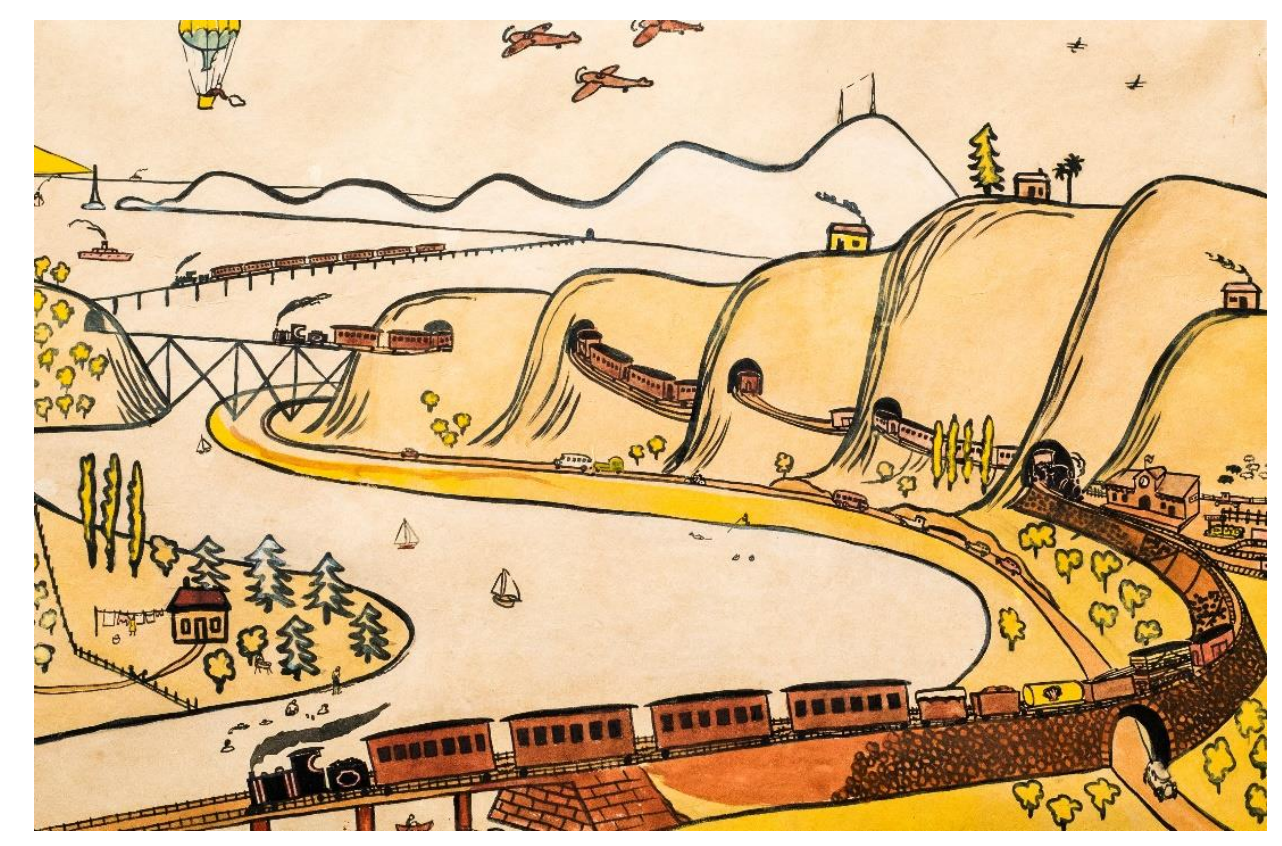

Figure 1. Colin and Anne McCahon, Untitled children's drawing, c. 1944. Ink, pen and watercolour on paper, $275 \times 378 \mathrm{~mm}$ (courtesy of the Colin McCahon Research and Publication Trust).

\section{Trains \& Boats \& Planes}

I was lucky enough to grow up with a McCahon children's painting on my bedroom wall; one my parents acquired in the immediate post war years. They were living in Dunedin, where my father was training to become a teacher of physical education ("physed") and my mother, though a qualified speech therapist, worked as a relieving primary school teacher. They were childless but planning to start a family soon. Among their friends was Noel Parsloe, also training to become a teacher. Noel, during the war, enlisted in the air force at the same time as my father did. He married Beatrice McCahon, another teacher, and Colin's older sister and it was Beata who gave the painting to my parents in anticipation of the birth of my eldest sister Virginia in Wellington in December 1947. It must have been one of those left unsold after the two exhibitions of paintings for children Colin and Anne McCahon held at Modern Books in Dunedin in 1945. 
My parents were of a generation of idealists who wanted to change the world for the better and sought to do so in a practical manner. My mother's speech therapy, for which she had a passion, and which she continued to practice over the years, was dedicated to improving the communication skills of children with a disability, whether physical, like a hare lip or a cleft palate, or psychological, as in the cases of those who stammered or stuttered. Among my father's books was one called The Education of the Ordinary Child, by John Duncan; it is a manual, with exercises, published in England in 1942 and I know he used it because I have it still and it is annotated in his hand. Their idealism was shared by their fellow teachers and by contemporaries like Anne and Colin McCahon. One of their beliefs was that, with the right sort of education, children grow up happy, healthy and strong; and will themselves then contribute to the betterment of the world.

My parents' commitment was to teaching, and later, for my mother at least, writing; the McCahons was to art; and I still think that children's painting was educative for me. I spent a lot of time looking at it, trying to unravel its complexities, which are mostly of the logistical kind. I called it Trains \& Boats \& Planes because it shows the progress through a landscape of hills, valleys, seas and skies of various forms of transportation, including cars and trucks and even a hot air balloon. I didn't know who painted it and I didn't care. No one ever said where it came from; but each time we moved, which we did quite often, it would reappear, like an old friend, on the wall of the bedroom where I slept. I had already taken imaginative ownership of it: I thought it belonged to me. All of this changed when, in the early 1970s, I found out that this hitherto innocent work was, in fact, that fabled thing, a McCahon.

Oddly enough, I can't now recall how I learned this. I do however remember the composer, Noel Sanders, in the mid-1970s in Wellington, telling me it was a collaborative work and that Colin painted the basic structure of the landscape and Anne coloured it in. Around this time, without asking anyone, I took the painting from the family home in Upper Hutt and hung it up on the wall of the house where I lived in Kelburn, Wellington; and later, in 1977, carried it with me up to Costley Street in Freemans Bay in Auckland. There I remember the painters Philip Clairmont, Tony Fomison and Allen Maddox coming around one night to have a look at it; the last time I saw Allen, almost twenty years later, he still had a detailed recall of it.

When, returning from overseas, my sister, its rightful owner, found I had purloined the painting, she reclaimed it; and has it still. She has had it conserved; but because no one in our family knew that water colour fades in sunlight, its reds and greens and blues have paled and it now has a fairly uniform brownish-yellow cast which, though far from what it would once have looked like, is still in its own way beautiful.

\section{Dark Night}

When I came to write my 2011 book, Dark Night: Walking with McCahon, that painting was the natural point of entry into the story I wanted to tell; but the inception of the work lay elsewhere, in the catalogue for the 2002 exhibition A Question of Faith, and specifically in Gordon Brown's account of McCahon's disappearance in Sydney in 1984, quoted in the chronology prepared by Steven Miller, Marja Bloem and Martin Browne and printed in the back of the book. I had various decisions to make before I could embark upon the writing of Dark Night; one was whether or not to approach the McCahon family about what I was intending to do. If I had been writing

Journal of New Zealand Studies NS31 (2020), 148-153 https://doi.org/10.26686/inzs.v0iNS31.6683 
conventional biography, I would have felt obliged to do so; but since I was not, I decided to go it alone.

There were several reasons for this. One was that I had heard, probably from Francis Pound, that the family could be "difficult"; another that I didn't really have anything I wanted to ask them; a third, most pertinent, was that I didn't know how the book was going to unfold: it was an openended inquiry which could have gone in any direction, including no direction at all. It seemed better to treat it as a frolic of my own. I did, however, make some use in it of an essay by William McCahon, Colin's elder son, from the catalogue for A Question of Faith.

I was anticipating Australian publication for Dark Night and so, for readers who might not be familiar with the life, I wrote a biography of the artist. About 12,000 words. Unfortunately, my Australian publishers, East Street Publications, ceased operations before the book was ready and I ended up publishing it in New Zealand. And the publishers there, Auckland University Press, didn't want the biography in the book. They said it was unnecessary; perhaps even insulting to local readers, who would already know who McCahon was. I wonder about that now; but at the time, I accepted their decision and the book appeared without the biography.

Some parts of it were controversial. During the research for Dark Night, for instance, I read in Agnes Wood's Colin McCahon, the Man and the Teacher an account by Chris Cathcart of a conversation he'd had with McCahon during which he claimed he had Jewish ancestry. His father, he explained, was descended from an Irish grocer from Belfast called Cohen who, in nineteenthcentury Dunedin, in order to disguise his origins (for commercial reasons) changed the family name to McCahon. Cathcart said: "You don't look Jewish"; to which McCahon replied: "But Jews can tell I am a Jew." At the same time McCahon also claimed, through cousins on his mother's side, Māori forebears. Ngāi Tahu perhaps? Were these facts; or were they rhetorical excursions made for the purpose of showing solidarity?

Chris Cathcart was Scottish, a sometime government meat inspector who, with McCahon and Frank Sargeson, founded the New Independent Theatre in Auckland towards the end of the 1950s, for the specific purpose of performing New Zealand plays. He spent the rest of his life, until his death in 2013, working in the theatre in Auckland. I have no reason to question his reliability as a witness; but I haven't attempted to research the question of McCahon's ancestry. Apart from Peter Simpson's mention of a family tradition that Ethel McCahon, née Ferrier, Colin's mother, had Jewish ancestry, ${ }^{1}$ no other scholar I know of has discussed these speculations. I do wonder, though, if they were one of the reasons AUP wanted the biography omitted from Dark Night. Curiously, given McCahon's history as a religious painter, the word "cohen" is derived from Hebrew "kōhēn", priest; the surname indicates that one's father's ancestors might have been priests at the Temple of Jerusalem.

\section{The Visitor Narrative}

Around the middle of 2019, out of the blue, I received an invitation from Vivienne Stone, Director of the McCahon House Museum Trust, to collaborate upon the rewriting of the Visitor Narrative for the McCahon House Museum in Titirangi in West Auckland. The museum is the small cottage above Otitori/French Bay where the McCahon family lived from 1953 to 1960. The information the docents were using, Vivienne said, was out of date. It needed renewal. 
The most interesting part of the task was its collaborative nature. I would be working with Finn McCahon-Jones, William's elder son, Colin's grandson. The eldest son of the eldest son. Later, and confidentially, I was told that part of the brief was to arrive at a narrative which might reconcile the sometimes hostile McCahon family to the activities of the Trust. This seemed beyond my capacity to achieve; but by the time I learned of it, I had already accepted the gig.

Over the decade since Dark Night was written I had more or less forgotten about my Life of McCahon; now I remembered it. At that point, neither Peter Simpson's nor Justin Paton's recent books - neither of which is, strictly speaking, a biography — had been published. And in fact there hasn't been a biography since Gordon Brown's book (1984; 1993) last century, and even that is focussed more upon the work rather than upon the life. So I got my version out and had another look at it. I thought it was okay, tidied it up a bit, gave it the title Endless Yet Never, and sent it off to Vivienne Stone: as a guarantee of my bona fides rather than a submission for publication, although the McCahon House Trust has since decided to publish it as a stand-alone work.

Subsequently, Vivienne forwarded the manuscript on to Finn; so that, when I arrived in Auckland to work on the Visitor Narrative, he had already seen it. This version included Cathcart's report on McCahon's alleged Jewish and Maori ancestry. What, I wondered, might Finn make of that? I also wondered, with that nervous anticipation you feel when you encounter people who may have read what you have written about them, or at least about their family, what he might think of Dark Night itself. In the event, Finn didn't comment upon Endless Yet Never; and, as for Dark Night, I'm not sure he knew it existed. I was both disappointed and relieved. It meant we could sit down to work together on the Visitor Narrative unimpeded, as it were, by past history or previous versions.

We took a geographical approach, working the narrative through seven parts, beginning at the garage at the top of the drive and ending in the glass and steel residence and studio, Parehuia, next door to the cottage; along the way pausing in the kitchen, the sitting room, the deck, the downstairs bedrooms, the garden, the bush and the beach. It involved retelling the story of the McCahon family in the 1950s, which rhymes in some respects with the story of my own family in that decade, when we lived in the remote mountain village of Ohakune and, like the McCahons, were involved with the practical demands of living out an idealistic commitment towards changing the world for the better.

There were, however, complexities. I soon became aware of silent witnesses to our enterprise. They were Colin and Anne's two surviving children: Finn's aunt Victoria Carr; and his father William, to whom, Finn said, he spoke on the telephone every day. I'd met Victoria briefly, once, at the seminar which began the project; she is both kindly and formidable. As for William, I have never met him; and yet there they both were, living presences for whom Finn was acting as a kind of medium. Or at least an interlocutor. I found this exacting and fascinating in about equal measure, unlike any other writing project I've been involved in.

By the end of the process - which, after ten days of face to face collaboration, continued for some weeks via email - we had a narrative we could both live with. Vivienne and the docents gave their assent as well. Whether our collaboration had in fact eased relations between the family and the Trust I do not know; but some of the negotiations between Finn and myself were certainly

Journal of New Zealand Studies NS31 (2020), 148-153 https://doi.org/10.26686/inzs.v0iNS31.6683 
undertaken in the interests of arriving at a commonly agreed version, which could then be transmitted by the docents to the general public. It would be interesting, one day, to take the tour, anonymously, as it were; but I don't suppose that's likely to happen.

\section{The Impossibility of Biography}

Because my mother became a well-known New Zealand writer, over the years I have met many people who knew her, some of whom seem to have encountered a different person from the one I remember. Amongst these were a few who contested my understanding of her character; and even demanded, implicitly if not explicitly, that I revise mine to accord with theirs. This of course I am unable to do; nevertheless, these encounters emphasise what we already know: there is no definitive version of a life, not even for a family which, like the McCahons, was intimately involved in the making of Colin's oeuvre.

One example: over the period of my collaboration with Finn, the question of McCahon's drinking underwent constant revision, during which he turned, for the purposes of the Visitor Narrative, from the raging, self-destructive, sometimes violent alcoholic of popular legend into a more or less benign social drinker, always susceptible to the designs of those who wished to get drunk with him in order to boast about it afterwards. The question of the use of alcohol as a fuel for his painting was elided, perhaps because it wasn't so much in evidence during the Titirangi years. Or was it? I don't know the truth of the matter and I suspect nobody else does either. Like my mother's character, it depends upon who you talk to.

One thing did not change: William's insistence, echoed by Finn, that it is the work that is important, not the life. Yet here too there are complexities. What are we to make of McCahon's assertion that all his painting was autobiographical? Perhaps what he meant was that you can see in the work the way his thought was developing; and the thought was based, as all our activities must be, in daily life, whatever that might have been at the time. The work may then be seen as the fruit of his youthful idealism, that ambition to alter the world for the better, as it evolved during the progress of a life which was profoundly and unremittently committed to change.

However, as the Greeks understood, there is a relationship between ambition and tragedy. Hubris can take many forms; one might be the temerity of thinking you can change the world for the better. What if the world does not change? McCahon in 1970 wrote to John Caselberg that he was facing the awful problem of being a better person before he could paint better. But what if you do become a better person, and you do paint better pictures - ethics and aesthetics in lockstep-and still the world does not change? One way of looking at the ambivalence between faith and doubt in the later paintings is as a reaction to the incipient defeat of his idealism, and the consequent despair.

In my father's case, his idealism also turned despair, for which he blamed himself. He thought his drinking was the result of personal weakness, undermining his ability to make the changes the world needed, while continuing to believe that those changes could still be made. Not that he considered himself a tragic figure. Nor, perhaps, did McCahon. Or maybe he did. However despairing he became, though, however physically and neurologically impaired by his addiction to alcohol, he didn't abandon his commitment as a seer, nor to the ambivalences the role demanded. Until he simply couldn't do it any more. This may be one way of understanding his decision to 
stop painting in 1982 or 3, in the terms used by Wittgenstein in the Tractatus: Whereof you cannot speak, thereof you must remain silent.

Families do know things no one outside the family can know. They are also inclined to believe their knowledge is comprehensive in ways not understandable by others. This may be so, but it is never the full story, especially where artists are concerned, because the effort of every artist is to extend what they have to say beyond its particulars towards some wider significance. Of course this effort almost always fails, but that does not mean we may then go back to the life to explain the failure; nor to explain whatever successes there may have been.

Trying to decode the work with reference to the life is like pulling up a plant to see if its roots are healthy. Or cutting open someone's chest to find out if their heart is still beating. Biographers can end up like morticians, laying out the body, embalming the organs, attempting to preserve the imperishable soul. After his death, Einstein's brain was extracted from his skull, pickled in alcohol, sliced up and the sections sent out to scientists for study: as if they might thereby learn something about the special theory of relativity. McCahon, too, might have been subject to post-mortem grotesqueries: someone proposed dissecting his eyes, as if understanding the mechanics of their optics might teach us something about his vision. The family, sensibly, put the kibosh on that.

It is really otherwise: no account of the life will explain the work, in the same way that the provenance of the children's painting that hung on the walls of the houses I grew up in can't explain its multiple effects upon the imagination of the young boy I was then. Our curiosity about others ensures there will always be lives of artists, and, indeed, of other kinds of people too. But in the end the life remains just that, the soil out of which the work has grown. Which, if it is well enough done, as McCahon's is, will take us places no biography ever can.

\footnotetext{
${ }^{1}$ Peter Simpson, Colin McCahon: Is This the Promised Land? Vol. II, 1960-1987 (Auckland: Auckland University Press, 2020), 316.
} 